\title{
Social impact and impoverishment risks of the Koga irrigation scheme, Blue Nile basin, Ethiopia
}

\author{
Irit Eguavoen (1), Weyni Tesfai (2)
}

(I) Center for Development Research, University of Bonn, Bonn, Germany

(2) Universität zu Köln, Köln, Germany

\begin{abstract}
The Koga project is the first new large-scale irrigation scheme in the Blue Nile river basin since the 1970 and may thus serve as an example of the tremendous changes of landscape and livelihood that are accompanying current water development projects in Ethiopia. This article analyzes the impoverishment risks arising out of the development-induced relocation of households in Koga. Following the Impoverishment Risk and Reconstruction model, seven of eight impoverishment risks could be identified, namely temporal landlessness, homelessness, joblessness, social marginalization, loss of household assets, social disarticulation and food insecurity, though the majority of relocated households succeeded in moving to other rural areas and did not face the challenges caused by urbanization. The Koga project and the local municipality undertook activities to reverse the impoverishment risk for the relocated households, but focused on the reconstruction of material livelihood assets (land, houses and compensation). The extent of rural-urban migration as a result of the project was underestimated. Proactive activities by the affected households succeeded in reducing their risk of impoverishment if they were informed early enough about the irrigation project.
\end{abstract}

Key words: development-induced displacement, impoverishment risk, irrigation, Ethiopia

\section{Introduction: Irrigation, landscapes and livelihoods}

Almost twenty years after Guijt and Thomson's "Landscapes and livelihoods" (1994) that underlined the socio-economic dimensions of irrigation, large-scale irrigation and hydropower projects in the Ethiopian Blue Nile basin are about to bring tremendous changes to the highland landscape and the livelihoods of many farmers. Politically, the government justifies these changes by arguing the alleged need for higher agricultural productivity in the country, for hydroelectric power to boost economic development and the need to have an adaptation strategy at hand when anticipated climate change will materialize and endanger food security. Though socio-economic assessments are part of every feasibility study nowadays and local livelihoods are considered in current irrigation studies, development interventions continue to be perceived as "project with sharp boundaries in space and time", which usually they are not (Guijt and Thomson 1994: 295). These 
authors point out that: "Irrigation is not necessarily beneficial. Changes in the physical landscape brought by irrigation also affect the social landscape, particularly inter- and intra-household relations." (ibid.: 299). Changes may destabilize households socially and economically for an intermediate or longer period and bear the risk of them becoming impoverished. This is typically the case with ho useholds affected by dam-induced relocation and land re-allocation. But it also applies in the case of the change from rain-fed agriculture (in combination with other income-generating activities) towards intense irrigation farming, which can lead to social destabilization and changes in intra-household relations.

This article analyzes the changes with regard to inter- and intra- household relations in the Koga irrigation project, with a special focus on relocated farm households that relocated to urban settings as a result of the dam project. Before presenting the findings, the Koga project will be contextualized in terms of development-induced relocation, hydropolitics and dam development in Ethiopia.

\section{Development-induced displacement and relocation in Ethiopia}

Displacement of people in the context or as a result of development interventions has been identified as "the most important forced migration problem worldwide" of our time (Pankhurst and Piguet 2009: 250; also De Wet 2006). In Ethiopia, displacement is prominent in development projects aimed at the extension of irrigation and of hydropower production, referred to as dam-induced displacement (Kebede 2009), and is claimed to be directed at the provision of better housing in urban centres (Gebre 2008; Tadele 2009), and at the conservation of forest or wildlife via national parks (Berisso 2009). But as has been pointed out in a recent volume, development-induced displacement in Ethiopia has become the "most significant type of movement replacing earlier concerns with resettlement, refugees, returnees and demobilization" (Pankhurst and Piguet 2009: 246).

The social impact of displacement and land loss due to the Koga irrigation scheme in the Amhara Region has previously been studied by Abebe et al. (2007) in the form of a technical consultancy report and in a stakeholder analysis by Gebre, Getachew, and McCartney (2008: 43), who stated, even before being officially inaugurated and operational, that "the project has a significant effect on the social landscape of the Koga catchment". The authors underlined the diversity of stakeholders and the differences in interest groups among local farmers living in the vicinity of the project. They pointed out that several types of affected farmers can be differentiated: displaced farmers, farmers expecting displacement, farmers in host communities, as well as farmers cultivating plots upstream of the Koga dam and not being part of the land re-allocation accompanying the project. This categorization hints at the fact that the development rhetoric of farmers as 'beneficiaries' must be critically reflected upon, because benefits are unequally distributed in the sense that some parts of the 'target population' may receive no benefits but be faced with an increase in poverty. As a result of infrastructural projects, notably when forced displacement occurs, such impoverishment may be triggered by landlessness, homelessness, joblessness, social marginalization, loss of assets and social disarticulation, and become manifest in the form of food insecurity and increased mortality rates, as summarized in 
the Impoverishment Risk and Reconstruction (IRR) model (Cernea 2005). Livelihoods that are lost must be re-established by the displaced households, who, in ideal circumstances, are supported by local authorities and adequate compensation schemes.

Many studies on displacement in Ethiopia have focused on the displacement of high numbers of households, often in the thousands. The Koga study sheds light on displacement involving a smaller number of households and involving short distances between place of origin and new homestead. Therefore, here the term 'development-induced relocation' seems more appropriate. Relocation in our understanding includes the notion of involuntary displacement. However it does not necessarily show coercion or imply the use of force by the authorities or a move to an unfamiliar environment. Relocation in our understanding implies agency of the displaced households who are able to make decisions on where, and to an extent, under what conditions to move. Relocation, however, not only implies moving to another place. It may also imply the movement to less fertile land or a change in lifestyle that was not intentionally chosen by the household.

Water dam-induced displacement and relocation has a history in Ethiopia. A prominent case is the first Gilgel Gibe dam, that between 1985 and 1996 , resulted in the displacement of "some 10.000" people (Kebede 2009: 50). In the Awash Valley, pastoralists were severely affected by the Koka dam and irrigation scheme (Gebre and Kassa 2009). Uncontrolled inundation of the Fincha'a reservoir in the Blue Nile basin constructed during the 1960s-70s and extended in 1987 forced around 3.100 farm households to move to former grazing land as well as to the steeper slopes after their houses were flooded. Others migrated to urban areas (Tefera 2006; Tefera and Sterk 2008). At the moment, an international campaign, the "Stop Gibe 3 ", is fighting against the prospect of displacement at the Omo River location where the Gigel Gibe III dam will be finalized in 2013. One of the arguments against the project, as claimed on the campaign's homepage ${ }^{1}$, is the expected displacement of about 3.400 farmers in Ethiopia, although the main issue under debate is the anticipated negative downstream impact of the dam reaching into areas in Kenya, especially the level of Lake Turkana, and possibly affecting 300.000 people who live north of and near the Lake. Downstream ecology and livelihoods are likely to be damaged. Because the area is settled by minority groups with distinctive cultural features, dam opponents also fear severe damage to the area's cultural heritage. Both the interests and communal land rights of the downstream inhabitants were either not considered by the dam planning experts or declared to be of minor interest when seen against the benefits of national hydropower development as well as the benefits of Ethiopian energy exports.

Dam development in the Blue Nile basin has drawn international attention mainly because of the hydropolitics over the Nile resources. At the local level, displacement will certainly be an issue in the other ongoing dam projects along the Blue Nile such as the Gumara dam, the Ribb dam and the Grand Millennium dam. 
The Koga project is in a more advanced stage already than Gilgel Gibe III, and socioeconomic change faced by a group of ca. 500 farming households that had to relocate their homesteads due to the Koga dam can be empirically investigated. As will be illustrated below, the extent of dislocation was much smaller than in other large-dam projects. The households, however, have experienced the loss of livelihood assets and went through a formalized process with the aim of receiving compensation for these losses.

\section{Water Development in the Upper Blue Nile basin}

The irrigation scheme draws water from the Koga River, one of 50 tributary streams joining the Ethiopian Upper Blue Nile known as Abay. At a size of $176.000 \mathrm{~km}^{2}$, the Abay River basin offers an estimated irrigation potential of $760.000 \mathrm{ha}$. Despite this potential, irrigated land use in the Abay River basin was measured at a mere 30.000 ha in 2002 (Moges et al. 2010). The Abay River basin spreads over three regional states: Amhara, Oromia and Benishangul-Gumuz, a rural area within which about ninety per cent of the basin's 600.000 inhabitants live. They depend on a livelihood strategy combining rainfed agriculture with animal husbandry. Droughts, the decrease in per capita food production, and dependency on food relief, even in years with regular rainfall, demand longterm strategies to attain food security and mitigate rainfall variability. The development of large water storage and irrigation facilities is part of the government strategy to deal with the challenge of intra-annual water variability. However, besides the undoubted opportunities, " $(t)$ he new rush into large-scale irrigation is inviting a number of problems", as stated by Moges et al. (2010: 83), entailing social and environmental consequences for the people living in areas surrounding the new water projects.

As the Abay River is the largest tributary of the Nile, sharing its water has for many decades been a sensitive political issue between the riparian countries Egypt, Sudan and Ethiopia (Ársano and Tamrat 2005; Kagwanja 2007; Cascão 2008). Ethiopian water development is supported by the Nile Basin Initiative, a forum in which riparian states struggled from as early as 200 I to ratify the new Nile River Basin Cooperative Agreement. Ethiopia was among the first five countries to sign the agreement in 2010. One more signature is required for the ratification, which has been opposed by Egypt and Sudan since the beginning of the initiative (Swain 2002; Salman 201r). During the past decades, large dam development in Ethiopia was politically hindered by Egypt and Sudan, but in 2002 was declared a national priority under the present Ethiopian government in the form of a 15-year water sector development programme. Planning for the current large dams in the basin had already started in the mid-Iggos. The first consultancy reports that suggest dam development date back to as early as the ig6os (Conway 2000) and the four dams proposed at that time (Mabil, Karadobi, Mendaia and a border dam) are continuously reassessed or under construction (Block 2007; Johnston and McCartney 2010). The current implementation of the Grand Millennium dam close to the Sudanese border is one of the long delayed realizations of these suggestions from the 1960s. Apart from the international policy context, a number of other factors contributed to the long neglect of large-scale water projects in the basin such as droughts, very high investment costs, poverty and social conflicts (Moges et al. 2010). 
The hydrological conditions, agricultural systems and landscapes in the Abay River basin, however, are undergoing tremendous changes as a result of new dams and the introduction of a number of large scale irrigation schemes, such as the Fogera Plains east of Lake Tana (Eguavoen et al. 20II). At the same time, there is an initiative under way to declare Lake Tana and upstream parts of the Abay River basin a UNESCO biosphere reserve - a project supported by the Ethiopian government, but which seems to stand in conflict with the further extension of large-scale irrigation and agricultural intensification in the same area ${ }^{2}$. Furthermore, the increase of national water storage is communicated by the government and researchers as one strategy to meet the challenges of anticipated climate change, without yet being able to provide sufficient empirical evidence for the suitability of this strategy (Eguavoen et al. 20Ir; Eguavoen and zur Heide, 2012). The Koga irrigation project has to be understood in this very dynamic context. It is the first large dam project undertaken in the Abay River basin since the extension of the Fincha'a reservoir in 1987 , as well as the first large operational dam project in an ongoing series of projects. This is why the Koga irrigation project gains significance as a pilot case with regard to water projects in the river basin implemented in the near future. There is high interest and demand in research findings which can inform the planning and implementation of dam projects in Ethiopia as well as future social research on the current regional dynamics (Eguavoen 20II).

\section{Methods}

The ethnographic study presented here was conducted during six weeks from February to April 2010 in Merawi, a small town about 35 kilometres south of the regional capital Bahir Dar, where the student researcher was hosted by the Koga Project Management Unit. In the same period, a second student researcher worked on organizational change and project management in Koga which allowed the exchange of data and information about farmers' conditions in the command area (Marx 20II). Furthermore, the study was integrated in a larger interdisciplinary research project.

The archive of the Koga Project Management Unit was accessible for the collection of secondary data, such as project reports. With the help of a research assistant recruited from Bahir Dar University to help with the Amharic translation, 35 households who had moved to Merawi due to the inundation of their homesteads, as well as 15 households who hosted the new settlers in their neighbourhood, were visited on a regular basis and interviewed (including standardized interviews). The student researcher Mrs. Tesfai joined some of them in their activities (e.g. at the market, during meetings, at the payment office to collect compensation, in church, during Easter festivities) and documented her observations in a field diary. Focus group interviews were held with one group of housewives, one group of religious leaders and two groups of farmers, affected by the project in different ways. To capture experiences and perceptions of relocated households, 20

2 "The wetlands around Lake Tana are home to a large number of endangered migratory and several endemic bird species, whose habitats are threatened by development for irrigation farming and intensive livestock grazing." See http://www.succow-stiftung.de/ethiopia-feasibility-study-for-a-biosphere-reserve-at-lake-tana.html (accessed 07.03.2012). 
in-depth case studies representing the various household categories were developed. Participant observation also took place among the Koga project staff (engineering team and management team). The two student researchers lived in the project quarters and joined the staff on their work trips to the command area. More formal interviews and informal conversations were conducted with 28 staff members of local authorities involved in or related to the Koga project (Figure $\mathrm{I}$ ).

\begin{tabular}{l|c} 
Local Authorities/ Offices & No. of respondents \\
\hline $\begin{array}{l}\text { Amhara Region Environmental Protection, Land Use and Administration } \\
\text { Authority (AR-EPLUAA) }\end{array}$ \\
\hline Koga Community Organization and Reconciliation Committee (KCORC) & I \\
\hline German Technical Cooperation in Bahir Dar (GTZ) & I \\
\hline Ministry of Water Resources Amhara Region in Bahir Dar & 3 \\
\hline Females Affaires Office (FAO) & 2 \\
\hline Bureau for Agriculture and Rural Development (BoARD) & 2 \\
\hline Municipality of Merawi, including the mayor & 6 \\
\hline Mecha Woreda Information Desk in Merawi & $\mathrm{I}$ \\
\hline Water Works Design and Supervision Enterprise (WWDSE) & 5 \\
\hline Mecha Woreda Capacity Building Center (MWCBC) & 3 \\
\hline Total no. of respondents & $\mathbf{2 8}$
\end{tabular}

Figure 1: Sources of information

\section{The Koga irrigation projec}

Koga is located in the Gojam Zone of the Amhara Regional State near the capital of Mecha Woreda, Merawi. The population of Merawi has access to a local market, basic health facilities, educational and administrative services and agricultural extension services. Electricity and water supply are generally available in town but are not extended to all quarters and to the periphery. Households without a water supply use a spring situated near the town. Mainly, the inhabitants of Merawi earn a living via agriculture or pursue off-farm occupations such as trade or services in the hotel, transport and restaurant sectors. Very few have a government job. The existing and future command areas of Koga where irrigation will take place lie some kilometres to the west of Merawi town, stretching to the north and south of the main road to Addis into the countryside, and are therefore less accessible for the farmers. 


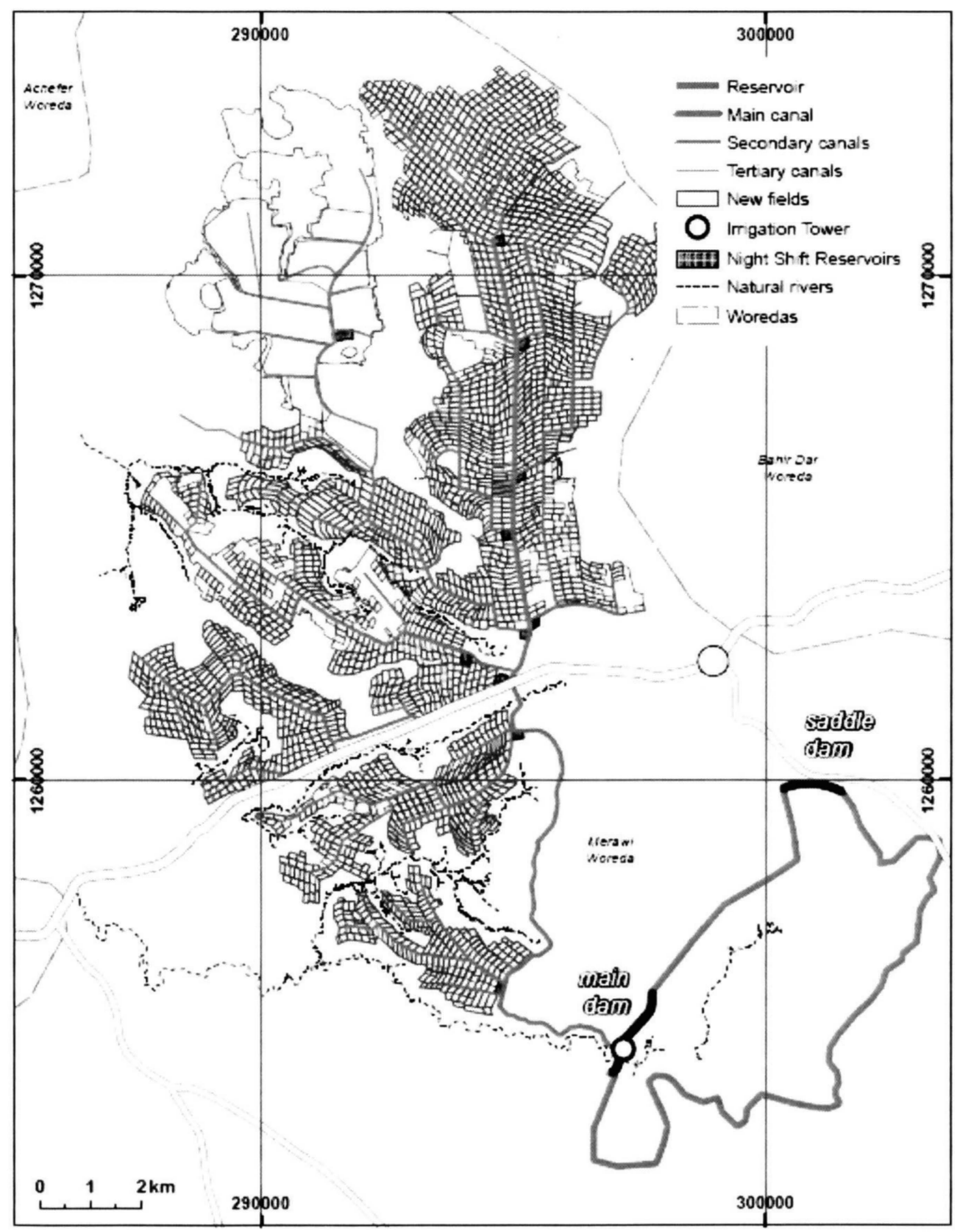

Figure 2: Map of the Koga irrigation scheme (source: Vigerske, 2008) 
The technical infrastructure of Koga consists of a main dam and a saddle dam which store water in a large reservoir. From there, water is released to a canal network leading to the farm plots. The canal network for the irrigation of 7.000 ha of land had not been completed when field research was conducted. During field research in March 2010 about 1.380 ha could be irrigated from the reservoir. Based on consultancy reports, the irrigable area in $201 \mathrm{I}$ was nearly $4.478 \mathrm{ha}$, but only 10\% of this area was also cultivated (WWDSE, 20II) due to a number of practical problems farmers were facing, such as lack of transport to distant farm plots.

The Koga reservoir inundated about 2,000 ha of grazing land and homestead areas. Settlements had to be given up and people left the flooded areas of five kebeles and relocated to either Merawi or to dry lands elsewhere in the woreda (district). A few islands are the only visible reminder of the former landscape, which is now dominated by the reservoir. The islands are used as pasture for cattle - even though this is a breach of Koga project rules.

Construction work on the canal system had been delayed for about four years, and during field research final completion was projected for the end of 20Ir. Delays, as well as the inevitable knock-on effects, were openly and frequently discussed in the monthly progress reports written by the construction and engineering firms in charge. The temporal extension of the project led to a much longer economic dependency on land loss compensation payments, as the time for the allocation of new arable plots shifted to an uncertain date in the future (see below).

In Mecha Woreda, households usually live in single homesteads or clusters of homesteads dispersed over the entire area. Most of the farm plots are situated within walking distance and gardens are cultivated nearby. The Koga project has changed the settlement pattern insofar as farm plots were reallocated in the 'command area', and that some hamlets were dissolved due to relocation. Plot sizes in the command area were reduced by land re-allocation into parcels of 0.5 ha and then divided, parts of which were allocated to relocated farmers to compensate for their loss of land due to the construction of irrigation infrastructure such as the dam, streets and canals. The land re-distribution was carried out on the basis of the Ethiopian Constitution of 1995 and the Federal Rural Land Administration Proclamation of 1997 , vesting all land ownership in the state and restricting farmers' property rights. As a consequence, local modes of land utilization are now dominated by labour exchange arrangements such as sharecropping (timado) and the employment of daily labourers (kenja). Irrigation had just started in three sectors of the command area. However, rain-fed cultivation could continue if land ownership was clearly spelled out and farmers did not face practical problems in accessing their plots.

The population affected by the Koga irrigation scheme cultivated on average household plots of about 2.I ha before the land reallocation; this was effected via rain-fed agriculture and with rather simple agricultural technology, i.e. ploughing with a pair of oxen, the use of small, localised river diversion systems for horticulture and low amounts of fertilisers, insecticides and pesticides, which were usually purchased from the agricultural extension office in Merawi. As a result, yields of grain are low and serve mainly as 
a source of subsistence, even though they are the main crops produced. Horticultural products such as peppers, onions and tomatoes are consumed but also sold, mostly at the largest local market in Merawi. Many households raised livestock that were grazed in communal areas now inundated by the reservoir. In fact, according to our interviewees, the inundated area was known to be the most fertile land available. Farming did not take place on these communal lands but on plots that were allocated to individual farm households by the authorities.

\section{Development - induced relocation in Koga}

According to Gebre, Getachew and McCartney (2007: 10), a total of 83 I households were dislocated in the context of the Koga project, and about 5.075 households experienced the loss of land and agricultural assets. A large number of additional households were affected by the construction of infrastructure for the Koga project, though their exact number remains unclear. Our field investigation revealed that the extent of dislocation was considerable. Before project implementation, consultations took place to identify possible locations where the affected households might live. Some households had to shift their house about fifty metres on their land plots to give way to canals or streets. Others, affected by the construction of the dams and inundation by the reservoir, had to move about three kilometres or more. They relocated their homesteads either to other kebeles where they had relatives, to other rural plots that were allocated to them, or to Merawi. Rural households situated in the area where the saddle dam was constructed moved to Merawi, which is located three kilometers away. The vast majority of relocated farmers, however, moved to places that were familiar to them already and not very distant from their former homestead (Figure 3).

\begin{tabular}{l|l|l} 
Kebele of origin & Kebele of destination & No. of households \\
\hline Kudmi (main dam) & Kudmi & $3 \mathrm{I}$ \\
\hline Abyot Fana (main dam) & Abyot Fana (Amusit) & 40 \\
\hline Enamirt (saddle dam) & Enamirt (Merawi) & 23 \\
\hline Inashenfallen (saddle dam) & Inashenfallen & I5 \\
\hline $\begin{array}{l}\text { Enamirt, Kurt Bahir, Inashenfallen } \\
\text { (inundation) }\end{array}$ & $\begin{array}{l}\text { dispersed to adjacent rural places/ } \\
\text { small towns }\end{array}$ & 366 \\
\hline Total & & 475.
\end{tabular}

Figure 3: Relocation of households due to the Koga project (Source: Merawi Town Municipality, March 2010)

People tried to move as neighbourhood groups, so that existing social networks were maintained as much as possible. Some relocated households in a town quarter called Merawi 03 said that their first preference was to move as an entire neighborhood group to the rural area close to the irrigable command areas. But places suggested by the Koga Community Organisation and Reconciliation Committee or KCORC turned out to be contaminated by malaria and other water-born diseases. According to the local leader 
of Merawi 03, many such visits to potential rural settlements were undertaken together with representatives of the KCORC: "At the end, there was no other alternative for us than to settle in town." ${ }^{3}$ Thus the entire context of relocation is very different from historical resettlement projects of Ethiopia where farmers were resettled in other regional states, among other language groups or to environmental zones that they had not experienced before. Nevertheless, relocated farmers in Koga lost their land and property and were entitled to receive compensation in terms of money and farm plots.

Merawi municipality estimates that about I6o households were affected by Koga and as a result had moved to the town. For these households, the move to town resulted in a series of changes: urban housing, dependency on food and labour markets, an urban lifestyle, new income sources, change in gender relations and in social networks. The relocated households in Merawi originated from five different kebeles directly affected by the two dams and the reservoir. During the time of research in 2010, 50 relocated households resided in two new quarters, called or and 03, on the periphery of Merawi. They formed the core sample of this research. Quarter or was established by Koga officials in cooperation with the town's municipality and quarter 03 by the households themselves. Electricity and water supply, as well as sanitation facilities, are wholly inadequate. Other relocated households in Merawi based in other parts of town and were also interviewed.

\section{Landlessness, loss of assets and compensation}

In the course of preparing the Koga project, the social and economic conditions of households living in different parts of the project area were assessed. Family size, livestock ownership and assets for agricultural production, housing type, water and sanitation supply and access to health care were all taken into consideration. The findings revealed that the former inhabitants of the dam and reservoir area were the wealthiest group, compared to households living in either the hilly upper catchment of the Koga project or the flat lands of the proposed command area (Gebre, Getachew, and McCartney, 2008).

Even though land ownership is vested in the Ethiopian state, households affected by the Koga project were entitled to adequate compensation for their loss of land use rights and other assets such as houses, gardens, trees and, above all, agricultural production capabilities. These losses were caused by the fact that people had to wait three years for new land plots in the Koga scheme (according to plan) and in the meantime were not able to engage in farming. Following article 1474 of the Ethiopian Civil Code, compensation may be forwarded in cash or kind, but should equal the cost of the damages caused by the respective project. Whilst in 2008 farmers believed that the long-term impact would outweigh the short-term social costs (Gebre, Getachew, and McCartney, 2008), in 20ro pessimism dominated the perception of the affected households, especially among relocated families in Merawi. 
In 2004, the KCORC was put in charge of relocation and compensation by the regional government. It assembled woreda representatives, staff from the Bureau for Agriculture and Rural Development and Officers from the Amhara Region-Environmental Protection/Land Use Administration Authority. The committee attended community meetings to enhance farmers' participation prior to construction. Other local authorities were also invited to facilitate the assessment of existing assets and to negotiate the amounts of compensation. As a result of this process, a total compensation cost of 30 Mio ETB was assumed for the Koga project (Gebre, Getachew, and McCartney, 2008). In practice, the assumed reimbursements were not fully paid, as in the case of compensation for the loss of homesteads. These were initially estimated at around 8.000 ETB per house, but actually only amounted to between 3.000 to $5.000 \mathrm{ETB}$, and this was far too little to cover the construction of a new house.

Compensation payments were made many months after the assets were lost and when dam construction had already begun. When workers from Chinese construction companies ${ }^{4}$ demolished property during construction, they were met with violent resistance by farmers. As the administrator and security officer of Merawi pointed out, most resistance occurred in cases when destruction was carried out before farmers assets had been officially estimated for the determination of compensation. Finally, the Merawi security office was asked to intervene, after which the conflict was settled peacefully through negotiations.

Apart from the delay and incompleteness in the assessment, rumours about the lack of transparency and propensity for favouritism also circulated. One interviewee stated, "I know, and I'm very sure about corruption going on in this project. I know one guy who received a total amount of 25,000 Birr for his eucalyptus trees, while another man received only 6,000 Birr for exactly the same amount of eucalyptus trees." 5 Of course, such statements are very difficult to verify empirically. Nevertheless, they indicate that the detailed criteria for defining compensation were not easily understood. Also, the delay in construction had a negative effect, as it was only in 20ro, some five years after the loss of land, that farming was possible for many relocated families, and then only through seasonal land renting and sharecropping arrangements within their kin network or through urban dwellers.

The implementation of the assessment was also criticised by the majority of the farmers, especially because it recorded selected assets but neglected others considered important for livelihoods such as the loss of communal grazing land and state forest for the provision of fuel wood, charcoal and honey. The last two were not considered because the ownership or use rights were not allocated to single households. Instead, grazing land and forest were common pooled resources owned by the state.

As a result, it was not only farming that was abandoned for some years. Livestockrelated occupations also had to be given up by many households, including the sale and

China Jiangxi Corporation for International Economic and Technical Cooperation and the China International Economic and Electric Corporation were assigned to the construction of the dam as well as the irrigation system (Marx 2011:25). 
production of dairy products: "Before, my wife used to sell milk, butter and cheese - of which we had plenty: But unfortunately we had no other choice than to sell most of our cattle, since the town has a limited capacity for livestock. So I gave three oxen and cows of mine to my relatives in Kurt Bahir, where they take care of them. Sometimes we go there to take some milk or cheese, but in case I get my farmland, I'll use them to plough my plot." ${ }^{6}$ The Koga project documentation reveals that some of the mentioned constraints of compensation were known and acknowledged by the local authorities. The Environmental Management and Monitoring Plan Report vol. II (2005) suggested compensation packages coupled with the establishment of employment and training programmes to counterbalance the loss of livelihoods caused by the project. In 20Io, both of these recommendations had still to be initiated.

The management of land reallocation took place under the auspices of the Amhara Region Environmental Protection/Land Use Administration Authority in Bahir Dar, whilst the practical distribution was conducted by the Koga Project Management Unit in Merawi. Land reallocation is legally backed up by regional land laws that allow the appropriation of land use rights in the interest of irrigation development. Of course, housseholds holding land rights in the command areas were not always happy to lose up to 20 per cent of their land plots, depending proportionally on the size of their land. Project laws issued by the World Bank and ADF have given priority of allocation to households that have to be compensated. According to KCORC, the redistribution is organised chronologically following the alphabetical order of the names of farmers to be compensated; it is not organised spatially by kebele affiliation, which means that it did not accommodate farmers who had adherent farm plots and work arrangements before. However, irrigable land can only be allocated and farmed once the construction of the canal system has been finalised, which is not yet the case in nine of the twelve command areas.

Even when compensated with a land plot, households continued to face challenges in farming due to the greater distance between place of residence and the new plots, which were located about $8 \mathrm{~km}$ from Merawi and could only be accessed via the main road. "The distance between my house and my plot is 9-10 km away, which makes the situation more difficult. How can my family cover the increased workload required for irrigation farming, when the plot is so far away? We can't afford to pay transportation for the whole family [...] Walking on foot is dangerous in this area, as car accidents occur sometimes. [.... I still haven't cultivated my plot, which I received last year."7 There are regular transport services in Merawi which link to irrigated areas in Kudmi, but not everybody can afford the fares and, of course, local transport cannot cater for the two oxen needed to plough the plots.

Another challenge is farm plots that previously hosted eucalyptus trees, which in the view of the farmers render the land infertile and dry. In many cases, the roots remained in the soil after the former owners cut the wood for sale before handing it over for reallocation. Other plots have such uneven surfaces after the removal of tree roots that farming is not yet possible unless land levelling has been conducted with heavy machinery. 


\section{Urban sources of livelihood}

The outcome of compensation payments differed appreciably among the affected households and thus their economic condition during field research. Some households were compensated for their lost house, but not for the land on which it stood. Other households received the correct amount of compensation but were not asked immediately to leave their land plots, meaning they could continue to cultivate on their 'lost land' for another season. Thus, these farmers benefited from the compensation scheme. Some households again could still draw from the compensation money they had received to contribute to their sustenance in Merawi. They entered sharecropping arrangements within their kin network and through urban dwellers or bought food at the market to sustain their families. Three better-off households were observed trading in agricultural crops between Merawi and Bahir Dar. According to the authorities in Merawi, there is a handful of other households involved in trade. Some relocated families have built houses in Merawi but continue to reside in rural areas. Their income was based on renting out the urban house to relocated families and other people. The livelihood portfolio of relocated households coming to Merawi has thus changed dramatically. With the loss of land and livestock, alternative income-generating strategies had to be developed. In this respect the relocated households succeeded to some extent, as shown in Figure 4 . The main shift in occupation was from subsistence to market-based provision of household goods and services with the consequence of an increased dependency on money in the household economy additional to the compensation money received by relocated households. 

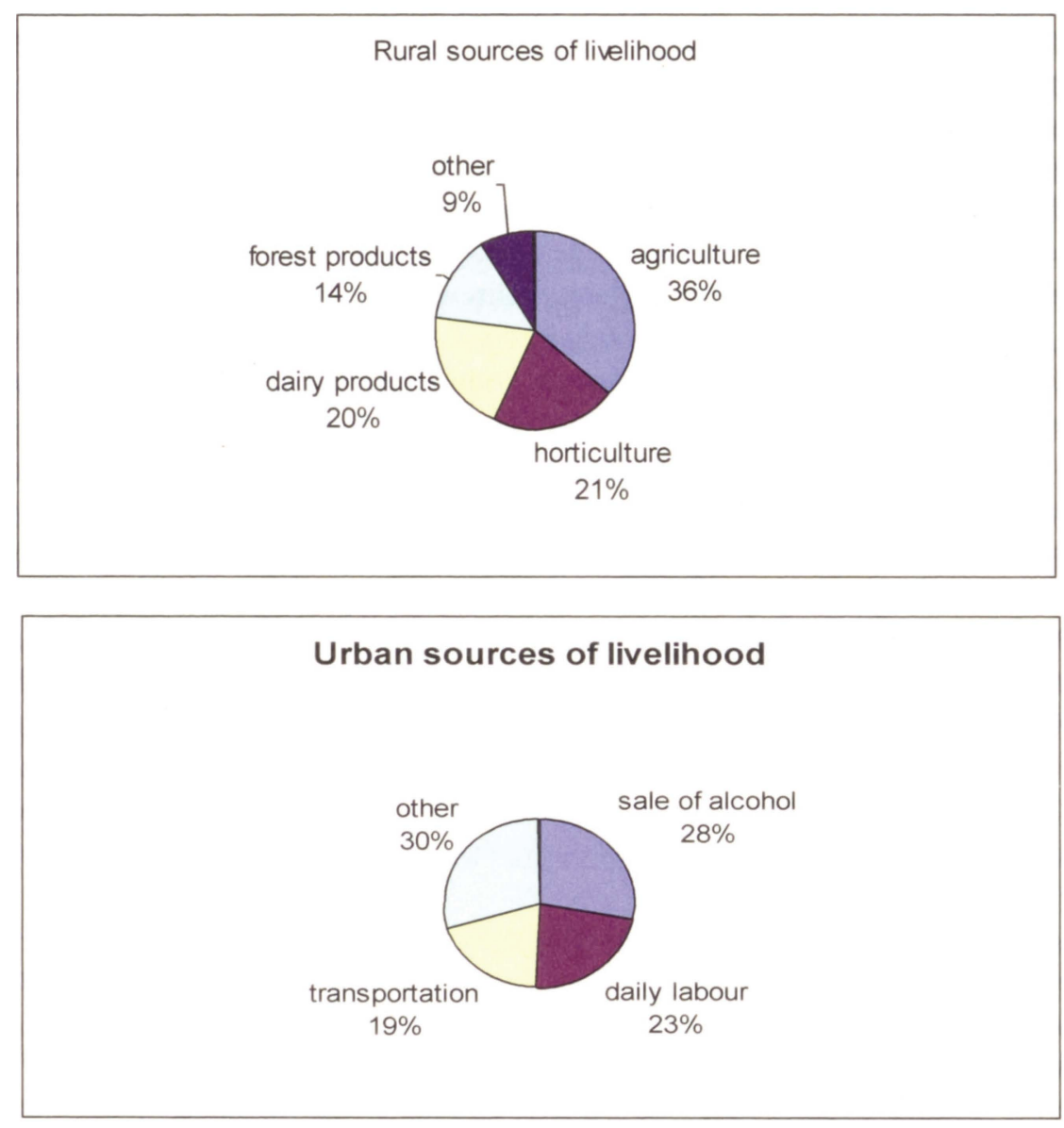

Figure 4: Income sources of relocated households in Merawi (source: Standardised interviews with 17 households, April 2010)

Due to their low level of education, relocated household members find it hard to gain urban employment, resulting in psychological stress and frustration. Most men look for construction work in the irrigation scheme, carrying loads with donkey carts, or even consider labour migration, although the pay is very low: "The Chinese pay us 17 birr a day. As you know, one breakfast costs about six birr. How are we going to feed our family from that small amount of money? Sometimes we work 16 hours a day, and it's really hard and exhausting work, but they refuse to give us more salary." Additionally, "Nowadays I'm so tired. Town life is so difficult since there are no jobs for illiterate people like me. Previously I possessed two quada of land 
[about 0.5 ha]. Imagine, I started ploughing when I was eight and now I'm 27 years old and just carrying stufflike a quatero [carrier, person who doesn't spend money] to earn a little money. ${ }^{88}$ Women have started to produce alcohol for sale. The gender-specific distribution of labour and the role of the male as breadwinner,both prevalent in rural farm economies, are not easily applied to the urban context, which brings additional problems into the families - in some cases even social disruption, alcoholism and an increased vulnerability to HIV/AIDS due to the increase of prostitution in Merawie that occurred as a side effect of the dam construction and the compensation payments. ${ }^{9}$

\section{The challenge of legal housing}

Homelessness as such was not a problem among the relocated families as they usually had received compensation payments to finance house construction. But the legalization of land plots on which to build houses turned out to be a challenge to a number of relocated households as the sale of land is not allowed in Ethiopia. To receive land plots for construction, arrangements of changing use rights to plots had to be found between town dwellers and incoming households. When the Koga project was announced land in the two formal resettlement sites (Merawi or and 03) was usually exchanged against rural land plots in Bojar Enamirt. One relocated farmer told us about this land exchange arranged about ten years ago: "When they [the authorities] informed us about the project, I knew I would lose my land and since I have no additional land somewhere else in the rural area, we had to move to the town. So what I did was an arrangement with one of my relatives in town who owned this piece of land where I have lived with my family now for 2 years. In exchange for that I gave him a piece of land which he cultivated until the launch of the project. By that time we legalized this arrangement officially at the Municipality, so that we both benefited and on top of that were compensated in terms of irrigated plots in Inguti." ${ }^{10}$ According to the mayor of Merawi, this practice is legal and common. Lack of infrastructure (water, electricity) is a common problem in other newly established quarters on the periphery of the town, and so is not a problem limited to relocated families.

The head of the Koga Community Coordination and Reconciliation Committee claimed not to know about the quarter Merawi 03, where more than thirty relocated households received their plots via private land exchange arrangements. Plots for houses in Merawi or were organized by the same committee in cooperation with the municipality.

But not all relocated households had prepared land exchange arrangement as described above nor received plots from the committee. These households had to arrange land under time pressure, leading to unregistered land exchange with and land sales from town dwellers which are categorized as illegal. Houses built on these sold plots did not receive permission and were built at night to elude the authorities' attention. If patrolling administrators detected such a 'moon house', it was declared and had to

9 Customers were reported to be Chinese workers as well as farmers who had received cash compensations. 
be torn down within one week before it would have to be demolished by the town officials. Households lived in great despair afraid of losing their new home and property while waiting for the legalization of their land exchange. Often, they had invested all their compensation money in the construction of the urban house. Households without land exchange arrangements had to build a house somewhere to find a homestead and were even more insecure about their urban housing plot. During the period of research 17 applications for legalization were ongoing. Legalization can be denied by authorities. The house will be destroyed without compensation and the households will then have to move into rented accommodation. Not being able to show the legal documents of the house also entails not having access to credit, loans from the bank or other formal financial institutions. According to town planners from the municipality, Merawi or and 03 will be fully integrated in the town's administrative zone, opening access to its formal saving and credit associations.

\section{Relations to the host community}

Accounts from relocated households and Merawi town dwellers indicate that from the beginning relocated families were not welcome in the host community. They were easy to spot within the town due to different clothes and behaviour. To speak of social marginalization is not entirely accurate, as they were not denied access to services based on their origin. The source of hostility was compensation. A few urban dwellers showed solidarity with the newcomers and helped them to get water and electricity, but initially town dwellers did not make it easy for the relocated families to integrate into urban social networks. They rather insulted them as being 'backward': "To your surprise, we used to live not far from this town, but in the beginning they considered us as a strange ethnic group, especially the insults that were hurled at our females was shameful for us and created bad feelings for us, but we just tolerated all these things, thinking that tomorrow we're going to live peacefully." ${ }^{11}$ The background to the insults was twofold. Urban dwellers had to give out land for the new settlers to cultivate. Further, they suspected them of gaining large financial benefits from the Koga project. However, over time, the urban dwellers came to realise that the former well-off farmers faced economic difficulties: "When we used to live in rural Enamirt, the whole city benefited from us, because we had vast land where we were able to collect many crops and grazing fodder and the surplus we sold in the market here in town. [...] When they saw me in the market buying fodder and crops, they understood my problem, realised that we were not rich like they suspected before and accepted me. After this, when I start a transportation service for them, they better understood my problem and started to say, 'Really, he is a poor immigrant, he is not rich and privileged'."' Ultimately, the cultural unity expressed in terms of language, customs and social organization between the rural and urban Amhara population did not provide much reason for discrimination.

\footnotetext{
II Mr. Dagne, 12.03.2010, Merawi or.

I2 Mr. G. Wale, 24.03.2010, Merawi o3.
} 


\section{Membership in local associations}

Social disarticulation, inter alia social destabilization, and the disruption of social ties were among the risks identified by Cernea in his model of 'impoverishment risks' (2005). Indeed, membership in kin groups, Orthodox Church communities and other rural associations, such as funeral groups, provide reliable social networks in rural areas within Amhara Regional State. In addition to providing room for social interaction, these groups contribute to livelihood security by community-based insurance and credit schemes. Dercon et al. (2006) illustrate that funeral associations (sing. iddir) are widespread in Ethiopia and share some common characteristics despite local variety. Funeral associations work like saving clubs and allocate funds, material and labour to member households in crisis (in case of death, but also illness, loss of assets, etc.). They may further provide loans and credit to their members who first pay entrance registration fee and then regular membership fees. Typically, households are part of several associations. Thus it is worth examining whether membership in associations has changed among relocated households in Koga.

The importance of local associations was obvious from conversations about former places of residence among relocated households in Merawi and elsewhere. Religious and funeral associations in particular displayed strong social and spatial ties and were kept alive even after relocation. The association serves many purposes, including providing moral support to its members in either difficult or more positive circumstances, such as funerals and weddings. Associations can further act as saving circles for private usage and for the provision of labour and money for church construction. Members of the rural association called Jegobez Mahaber (association of braves) indicated the main benefits besides social support, moral guidance and labour exchange are qurban (a funeral insurance) and the supply with oxen for ploughing: "In case one of our brothers is sick or gets arrested, we plough his land, otherwise his family is going to starve. The same as when a member loses his oxen, we contribute two oxen so that he can plough. ${ }^{{ }^{13}}$ Membership was observed to be male; wives and female relatives benefit indirectly. Local associations are thus perceived as social security networks of great value, as family members tend to join different associations to provide security for each other beyond financial security: "The reason why we join different [religious] associations is that since we are brothers. [...] we became members of two different associations, which are celebrated at different days, so that when I go to the ceremony he will guard the compound, and when he attends I become a guard for our houses." 14 After relocation, many of these supportive, saving and house-defending arrangements became obsolete.

Even though the networks created by the church and associations have not changed as such, a number of relocated households left such supportive groups because they were no longer able to afford the required membership fees after having lost their land and not being able to farm for a few seasons. Several farmers expressed their unhappiness about this: "We have lost our land and our properties, but the church personnel constantly demand financial

13 Mr. G. Wale, 24.03.2010, Merawi 03.

14 Mr. A.Wale, 24.03.2010, Merawi 03. 
support to construct the churches. I suppose they are not [facing] problems as we are." 15 Some 20 individuals have shifted to a church close by to avoid the long distance traveling involved to attend their previous place of worship. Studies have found that some local associations limit their membership to a specific age group or gender (Dercon et al. 2006). In the field site, membership of local associations is granted to male household heads, which means that widows and divorced women and their households stand outside and are unable to enjoy the association's support, even if they can afford to pay to join. It should be noted, however, that this gender imbalance in accessing local associations seems to have already been in place in the region long before the Koga project.

During festive events conducted in Merawi or and Merawi 03, it became clear that the relocated households relied on their families, associations from their former settlement and old neighbours rather on the urban associations or new urban social networks created through the neighbourhood or common occupation, albeit that town dwellers and relocated families were linked to each other through market activities before the Koga project. In practical matters, town dwellers and relocated households started to cooperate to organize water and electricity supply and establishmed a vigilante group to protect the quarters from thieves. In fact, the common security force acted as a key factor of social integration. "The village committee in this kebele, in which this association keeps villages secure together, helped us to create a peaceful life. This facilitated us getting to know each other and facilitated our interconnection. [...] Now, since we know each other better, sometimes we take credit in shops or bars, and in return we give them credit in selling firewood or dairy products." 6 Thus, the first steps towards social integration have been achieved. Once the relocated farmers can restart farming on irrigable plots, enjoy security with regard to urban housing and assure their livelihood, their social-economic situation may hopefully become stable once again.

\section{Conclusions}

As a result of their 'stakeholder' analysis, Gebre, Getachew, and McCartney (2008) listed a number of key findings, which were confirmed by our ethnographic study. What they called " $a$ sharp conflict of interest" between relocated households and their host communities (ibid., 2008: 40) could still be observed, even though due to the delay in project implementation, members of the host communities came to realise that the relocation often had a negative impact on the livelihoods of the relocated households. The risk of running out of compensation payments had been predicted by project documents (Gebre et al. 2008). In 2010 a number of households faced this situation of not being able to take up farming again. They had no money left from the compensation source to buy food items and faced food insecurity. The study shows that in addition to the loss of land and property, and the delay and irregularities in compensation payments, the project was accompanied by processes of social disarticulation. As a major cause of this disarticula- 
tion, identified by the studies, was the change from a rural to an urban environment and its consequences in terms of social networks, livelihood systems (from subsistence to market-dependence) and gender relations within households. Many of the relocated households had to start from scratch, even though some could build on existing social networks to some extent to ensure temporal access to farmland. The studies also show that socio-economic integration is a slow but ongoing process in Merawi that will take some years to come to full fruition. The economic and socio-political position of the relocated households will probably improve once they finally receive and can practically access their irrigable land plots, especially because there is no language or cultural barrier to hinder social integration.

If the high expectations associated with the Koga project materialise in terms of household earnings through irrigation, from which, according to the plan, about $\mathbf{1 4 . 0 0 0}$ households may benefit, an increase in rural-urban migration to Merawi can be assumed. About 98 per cent of the interviewees would "build a house in the city" in such a case. For people over 30 years of age, Merawi is still perceived to be a difficult place to live, but this does not alter their intention to send their children to live in the town if this course of action results in a better education. The prospect of their children leaving the farms behind and striving for other jobs seems to clearly outweigh the parents' fear of problematic social integration in unfamiliar urban surroundings.

When relating the findings to the impoverishment risks of the Impoverishment Risk and Reconstruction (IRR) model developed by Cernea (2005), seven of the eight risks were clearly identified. (There was no reliable data on increased mortality). But it is also important to underline that the majority of relocated households succeeded in settling down in rural areas, thus did not face the specific urban difficulties. The Koga project as well as the municipality undertook reconstruction activities to reverse the impoverishment risks for the relocated households, even though they focused on the reconstruction of material livelihood assets, such as land and houses, and tried to deal with income loss mainly through compensation which can only serve as temporary relief. However, they seem to have underestimated the extent of rural-urban migration and the need for land in Merawi. The Koga Project Management Unit works very professionally, which manifests itself, for example, in project workers' considerable knowledge of ongoing social dynamics, as well as in a professional report and archive systems. The workers also often reflected on the role and activities of the Project Management Unit. Despite this, the payment of compensation and allocation of land could have been better organised and the negative consequences for livelihoods reduced. But it seems that reconstructive activities suffered mainly from the long delays with regard to the finalization of the canal system and the calculation of compensation for a shorter off-farm period. The reconstruction of access to commons (especially grazing land) was not considered - the irrigation scheme did not provide space for commons as grazing land was inundated by the reservoir and other commons were turned into farm plots.

Another striking finding is the proactive activities that were initiated by the affected households when informed early enough about the project, especially about the need 
to organise and to legalize land exchange arrangements. Proactive households found it easier to settle down in town or with rural relatives, as well as to ensure the temporary access to farm land to cushion the lean times until land reallocation and irrigation would be in place.

The main lessons that can be drawn from the Koga for future schemes in the Blue Nile basin include: a) that the period of the time farmers need to depend on compensation payments will have to be estimated more realistically, and b) that the development of other income-generating opportunities should not be neglected. The early communication of a situation to farmers as well as the administrative support of their reconstructive activities seems essential. Also the process of legalizing land exchange arrangements needs to be expedited with greater speed, to allow access to credit available to the new town dwellers (Eguavoen 20II). Finally, one can expect a wave of rural-urban migration to towns near the future dam sites which will require increased accommodation capacity.

As outlined in the introduction, there is a wealth of experience with regard to development-induced displacement in Ethiopia. Social and technical expertise within the country, as well as international expertise, is available to inform the planning and implementation of dam projects based on experience and knowledge. Temporal impoverishment risks for people living around the new water projects are perhaps not avoidable but can certainly be reduced. The crucial question is how far this expertise is appreciated or whether some projects are planned while turning a blind eye to the social consequences. It seems that behind the political call for more irrigation and hydropower projects there is still an inadequate appreciation of the dramatic implications these projects will have in areas such as landscape, biodiversity, and social and livelihood systems. The implication of large infrastructure development never stops at its project boundaries and defined targets, especially in water projects.

\section{Acknowledgement}

This work was part of the research project "Re-thinking Water Storage for Climate Change Adaptation in Sub-Saharan Africa" (2008-20II) under the leadership of the International Water Management Institute in Addis Ababa. We would like to thank the German Federal Ministry for Economic Cooperation and Development (BMZ) for funding and the Koga Project Management Unit for its kind hospitality.

\section{References}

Abutte, Wolde-Selassie (2000). Social-re-articulation after resettlement: observing the Beles Valley scheme in Ethiopia, in: Cernea, Michael M. \& Christopher McDowell (eds.), Risk and reconstruction. Experiences of resettlers and refugees. Washington, D.C.: The World Bank, 4I2-430.

Alemie, T. C. (2009). The effects of eukalyptus on crop productivity and soil properties in the Koga watershed, Western Amhara region, Ethiopia. MA thesis, Cornell University.

Arsano, Yacob \& Imeru, Tamrat (2005). Ethiopia and the Eastern Nile Basin. Aquatic Sciences 67: 15-27.

Berisso, Tadesse (2009). Planning resettlement in Ethiopia. The experience of the Guji Oromo and the Nech Sar National Park, in: Alula Pankhurst \& François Piguet (eds.), Moving people in Ethiopia. Development, Displacement and the State. Oxford: James Currey, pp. 93-ror. 
Block, Paul J. (2007). Integrated management of the Blue Nile basin in Ethiopia. Hydropower and irrigation modeling. IFPRI Discussion Paper 00700. Washington DC.

Cascão, Ana Elisa (2008). Ethiopia - challenges to Egyptian hegemony in the Nile Basin. Water Policy Io (2): 13-28.

Cernea, Michael M. (2005). Concept and method. Applying the IRR model in Africa to resettlement and poverty, in: Itaru Ohta \& Gebre Yntiso (eds.) Displacement risks in Africa. Refugees, resettlers and their host population. Kyoto: Kyoto University Press, pp. 195-258.

Cernea, Michael M. \& Christopher McDowell (eds.) (2000). Risk and reconstruction. Experiences of resettlers and refugees. Washington, D.C.: The World Bank.

Conway, Declan (2000). The climate and hydrology of the Upper Blue Nile River. Geographical Journal r66(I): 49-62.

Dercon, Stefan, Joachim de Weerdt, Tessa Bold \& Alula Pankhurst (2006). Group-based funeral insurance in Ethiopia and Tanzania. World Development 34(4): 685-703.

De Wet, Chris (ed.) (2006). Development-induced displacement. Problems, policies and people. New York - Oxford: Berghhan Books.

De Wet, Chris (2005). Some socio-economic risks and opportunities relating to dam-induced resettlement in Africa, in: Itaru Ohta \& Gebre Yntiso (eds.) Displacement risks in Africa. Refugees, resettlers and their host population. Kyoto: Kyoto UP, pp. 259-281.

Eguavoen, Irit (20II) Pro-active farmers and supportive municipalities in Ethiopian dam projects. ZEF Policy Brief 9. Bonn.

Eguavoen, Irit, Sisay Demeku Derib, Tilaye Teklewold Deneke, Matthew McCartney, Ben Adol Otto \& Saeed Seidu Billa (2011). Damming, digging or diverting? Small-scale irrigation in the Blue Nile basin, Ethiopia. ZEF Working Paper 84 . Bonn.

Eguavoen, Irit \& Friedrich zur Heide (2012). Klimawandel und Anpassungsforschung in Äthiopien. Zeitschrift für Ethnologie 137 (I), I-22.

Haileselassie, A., Fitsum Hagos, Everisto Mapedza, Claudia W. Sadoff, Seleshi Bekele Awulachew, S. Gebreselassie \& D. Peden (2008). Institutional settings and livelihood strategies in the Blue Nile Basin: implications for upstream/downstream linkages. Colombo, Sri Lanka: IWMI.

Johnston, Robyn and Matthew McCartney (2010). Inventory of water storage types in the Blue Nile and Volta River basins. IWMI Working Paper 140. Colombo, Sri Lanka.

Kagwanja, Peter (2007). Calming the waters. The East African Community and the conflict over the Nile resources. Journal of Eastern African Studies I(3): 321-337.

Kebede, Kassahun (2009). Social dimensions of development- induced resettlement. The case of Gilgel Gibe hydroelectric dam, in: Alula Pankhurst \& François Piguet (eds.) Moving people in Ethiopia. Development, Displacement and the State. New York: James Currey, pp.49-65.

Marx, Sina (20II). The political ecology of irrigation management in the Blue Nile basin. Impacts of global environmental policies on local adaptation in the Koga irrigation project, Ethiopia. MA thesis, Cultural and Social Anthropology, University of Cologne.

Moges, Semu, Helmut Kloos, Stuart McFeeters \& Worku Legesse (2010). The Water Resources of Ethiopia and Large-scale Hydropower and Irrigation Development, in: H. Kloos, et al. (eds.) Water Resources Management in Ethiopia: Implications for the Nile Basin. Amherst: Cambria Press, pp. 63-ror.

Pankhurst, Alula \& François Piguet (2009). Displacement, migration and relocation, in: Alula Pankhurst \& François Piguet (eds.) Moving people in Ethiopia. Development, Displacement and the State. New York: James Currey, pp.246-264.

Rahmato, Dessalegn (2008). The Peasant and the State. Studies in agricultural change in Ethiopia 1950s-2000s. Addis Ababa: Custom Books Publishing.

Salman, M.A. (20II). The new state of South Sudan and the hydropolitics of the Nile basin. Water International 36(2): 154-166.

Swain, Ashok (2002). The Nile River Basin Initiative. Too many cooks, too little broth. SAIS 22(2): 293-308. 
Tadele, Feleke (2009). Urban development and displacement of rural communities around Addis Ababa, in: Alula Pankhurst \& François Piguet (eds.) Moving people in Ethiopia. Development, Displacement and the State. New York: James Currey, pp.102-118.

Tefera, Bezuayehu (2006). People and Dams. Environmental and socio-economic changes induced by a reservoir in Fincha' $a$ watershed, western Ethiopia, Wageningen: UP.

Tefera, Bezuayehu \& Geert Sterk (2008). Hydropower-induced land use change in Fincha'a watershed, western Ethiopia: Analysis and impacts. Mountain Research and Development 28(I): 72-80.

Vigerske, Martin (2008). 3D-Visualisierung des Projektes 'Koga Irrigation and Watershed Management'. Master Thesis, Technische Fach hochschule Berlin.

Yntiso, Gebre (2008). Urban development and displacement in Addis Ababa. The impact of resettlement projects on low income households. Eastern Africa Social Science Research Review 24 (2): 53-77.

\section{Koga studies and project documents}

Belete Abebe, Wubneh (2007). EIA implementation and follow-up: a case study of Koga irrigation and watershed management project - Ethiopia, Delft: UNESCO-IHE Institute for Water Education.

Gebre, Ayalew, Derese Getachew and Matthew McCartney (2008). Stakeholder Analysis of the Koga Irrigation and Watershed Management Project. A study report submitted to the IWMI. Addis Ababa.

The Environmental Management and Monitoring Plan Report. Vol. II (2005) (archived in Koga Project office in Merawie). 